\title{
Foreword
}

\section{Dr. Norman D. Brown: An Appreciation}

$\mathrm{N}$ orman D. Brown will be remembered as a distinguished scholar, beloved teacher, generous colleague, loyal University of Texas Longhorn, and devoted husband and father. Over the course of his lifetime (1935-2015), he wrote and edited a number of books on U.S. southern and Civil War history, but he is best known for his 1984 monograph Hood, Bonnet, and Little Brown Jug: Texas Politics, 1921-1928. At UT, where he taught from 1962 until his retirement in 2010, he stood out for his mastery of twentieth-century Texas politics, and he stood out among his colleagues and students in Garrison Hall-literally.

His children, David and Tracy Brown, are proud that their father, in their words, "inspired many students over his forty-eight years of teaching with his love of history," a sentiment they often heard from those who had studied with him. David notes that his father was fortunate to be able to make a career out of his passion for history: "I have fond memories of his dedication, working away at home day and night on his typewriter on his latest book project."

Norman was also masterful in amassing and collating information and quirky details about the state's politicians - their machinations and personal ambitions, their feuds with one another, and their quests for power, ill-gained or not. He spent many hours in the Eugene C. Barker Texas History Center (now The Dolph Briscoe Center for American History) poring over its archival collections. When classes were in session, he would come to campus early in the morning and proceed to the conference room on the first floor of Garrison Hall, where he spread out his rumpled, dog-eared notes for the day's lectures. Many mornings his colleagues in the history department also saw him hunched over the department copying machine, feeding it stacks of newspaper articles and obituaries. Later that day they would find in their department mailboxes photocopies relevant to their own 
interests, provided by the department's “one-man clipping service.” Norman was ever on the lookout for newspaper stories his colleagues would find enlightening or entertaining.

To have a word with him in his office on the building's main floor (near what is today the conference room), colleagues, undergrads, and graduate students would enter and wend their way through the maze of bookshelves and towering stacks of books and papers - and piles of those ubiquitous photocopied clippings - that ended at his desk. Norman was appreciated as an inspiring, knowledgeable, and caring teacher, for he possessed an uncanny ability to bring the past to life - to make it accessible to undergraduates and graduate students alike.

He was a giant in the field, but also a giant in real life-a large man, well over six feet tall, who commanded the attention of his colleagues and his students even as he impressed them with his gentle demeanor and wry sense of humor. Though reticent, he was an accomplished punster, with gems worthy of Austin's annual O’Henry Pun-Off World Championships. He rarely spoke in department meetings, but when he did, colleagues listened. He was unfailingly kind to junior faculty and graduate students in a time when rigid academic hierarchies based on tenure status could smother otherwise ordinary personal courtesies. Even during the last months of his life, he was eager to help students with their research, a reflection of his deep, abiding interest in Texas politics, past and present.

Norman Donald Brown was born in 1935 in Pittsburgh, Pennsylvania. His family moved to Kokomo, Indiana, where he completed high school. He went on to graduate summa cum laude from Indiana University and to earn his MA and PhD in history from the University of North Carolina at Chapel Hill. As an advanced graduate student, he began teaching history at the University of Texas at Austin in 1962, holding that lectureship until he was promoted to assistant professor three years later. He married Betty Jane Aldrich the following year. In 1969 he received tenure and the rank of associate professor. In 1983 he was promoted to full professor, and a year later was named Barbara White Stuart Centennial Professor in Texas History, an endowed chair he held until he retired twenty-nine years later. (A grateful former student provided the eponymous endowment for his chair.) He taught undergraduate courses on the Old South, the South since 1865, writers of the modern South, and the image of the South in nineteenth-century American literature, as well as the U.S. survey course. At the graduate level his courses included reading and research seminars in southern history and Texas in the 1920s. Unlike many conventional southern historians, early in 
his career Norman offered courses on slavery and spoke to wider audiences about lynching and the struggle for civil rights in Texas.

Norman was an excellent classroom teacher-low-key, well organized, and plainspoken. Appreciative of his carefully structured lectures, his undergraduates marveled, "He makes it so easy to take notes!" His exam essay questions and writing assignments forced them to keep up with the required readings, attend class regularly, and make a logical argument based on the facts at hand-all valuable skills they would draw upon for the rest of their lives.

His graduate students learned the fundamentals of historical research. Norman encouraged them to burrow into the archives to discover the facts behind Texas historical trends and events that had been rendered previously as myths or hearsay. For example, in the seminar "Texas in the 1920 s and 1930s" students mined (as deeply as they could in the allotted time) the raw primary documents that illuminated the Red River Bridge War between Texas and Oklahoma in 1931 or the gubernatorial administrations of Miriam A. "Ma" Ferguson and Dan Moody. He impressed on his students his conviction that the correspondence between relevant actors furnishes insights into their motivation. He also reminded them that political history encompasses much more than campaign speeches and vote tabulations, and he required that his students have an understanding of larger social, cultural, and economic contexts. Each graduate seminar culminated in student presentations, and Norman's insightful comments on each one represented a collegial effort that his students remembered and appreciated long after graduation.

His lengthy curriculum vitae, which covers thirteen single-spaced typed pages, is a fascinating historical artifact in itself, listing every book review Norman wrote and the title of every talk he delivered in addition to his publications and courses. Lopsided strips of paper with additions and corrections are stapled onto the pages - by the 1980 os there was no need to retype the whole document when only a single line here or there needed updating!

Norman was a good citizen of the UT history department, serving on virtually every committee at least once, and he participated in search committees and prize committees galore. He supplemented his service to the department by serving the university (on the Faculty Advisory Committee for the Lyndon Baines Johnson Library, for example) as well as by engaging with the larger public (as a member of the Texas Constitutional Revision Commission's local citizens' advisory committee in the early 197os). He served a term (1999-200o) as president of, and was an active member of, 
the Texas State Historical Association (TSHA), which was founded in 1897 by the first chair of UT's history department, George P. Garrison. Norman was also a longtime member of the editorial advisory board of the association's scholarly journal, Southwestern Historical Quarterly. He was named a fellow of the association in 1995 .

By the 1970s his books on Daniel Webster of Massachusetts and Edward Stanly of North Carolina had earned him a national reputation as a specialist in the history of late-antebellum politics. Edited volumes of the reminiscences and diaries of two Confederate officers, Capt. Samuel T. Foster and Capt. Elijah P. Petty, followed (in 1980 and 1982). For the latter book, Journey to Pleasant Hill: The Civil War Letters of Captain Elijah P. Petty, Walker's Texas Division, CSA, Norman won several awards, including a citation from the San Antonio Conservation Society "for a work of great beauty which conveys, as only letters can, the truth of a monumental moment in history." Other forms of recognition include the Earle R. Davis Award for Contributions to Texas-Confederate History, the United Daughters of the Confederacy's Jefferson Davis Medal, and the George Washington Honor Medal for Excellence.

The publication of Hood, Bonnet, and Little Brown Jug by Texas A\&M Press in 1984 marked Norman's turn toward twentieth-century Texas, a fertile field for any historian intrigued by idiosyncratic personalities engaged in bare-knuckled politics. Here were great tales to be told about contentious public policies and demagogic appeals to a largely white populace, all set against a national backdrop of partisan political intrigue. Norman shows how James E. "Pa" Ferguson was able to navigate the shoals of factional Democratic in-fighting and rise to power when he was elected governor in 1915. Ferguson was reelected two years later, only to be impeached by the Texas House of Representatives and convicted by a senate committee for misapplication of public funds, among other charges. Not to be denied what he considered his political due, Ferguson sought the Democratic gubernatorial nomination again but lost to William P. Hobby. Pa also aspired to the presidency and the U.S. Senate, ambitions that were thwarted by members of his own party. When Ferguson managed to get his wife Miriam A. "Ma" Ferguson elected governor in 1925, he returned to the governor's office and continued his corrupt ways with gusto. Hood, Bonnet, and Little Brown Jug also details the relatively brief but robust hold that the Ku Klux Klan had on state politics in the 1920s, when "others"-defined as immigrants and Catholics as well as blacks and Hispanics-became scapegoats for a depressed agricultural economy. Ma Ferguson's successor, the state's young 
attorney general Dan Moody, enacted good-government, progressive principles in an effort to bring efficiency and honesty to state government and to promote private business interests in the process.

This current volume, the sequel to Hood, Bonnet, and Little Brown Jug picks up that story in 1929. Soon after Norman's retirement in 2010, Josiah Daniel, a former student of his, generously provided resources to the history department to ensure that this new book would be published and receive the broad, appreciative readership it deserved. The first step was to convert the typescript to an electronic file, a time-consuming process that required considerable (human) effort to "clean up" and prepare the final version of text. The department then hired Dr. Rachel Ozanne, a newly minted UT history $\mathrm{PhD}$ who had been teaching Texas history, to edit the manuscript. Dr. Ozanne wrote an introduction to the study and enhanced the footnotes with sources published since the early 1980 , offering mini-historiographical surveys on relevant topics. Like Hood, Bonnet, and Little Brown Jug, this volume fills a gap in the historical literature related to Texas politics.

In keeping with Norman's playfulness in choosing book titles, Dr. Ozanne calls this study Biscuits, the Dole, and Nodding Donkeys: Texas Politics, 1929-1932, making reference to the volume's themes: Pa Ferguson believed that politicians should keep their constituents well fed with political "biscuits" by giving the voters what they wanted. The "dole" references the enduring tension between the federal government and the State of Texas, a tension exacerbated by the Great Depression, when the economic desperation of many residents challenged the state's historic emphasis on personal self-reliance and its traditional contempt for governmental social welfare programs. The "nodding donkeys" are the oil rigs that fueled the state's economy but also prompted calls for regulation in the face of a glut in the oil market during the 1930s.

Norman was most definitely a political historian in the traditional - even old-fashioned-sense of the term. At the same time, readers of his books and articles will find neither dry recitations of voter registration statistics nor explications of long-forgotten party platforms. Instead, he brings to life the personal dynamics that inflected Texas politics - the euphemistically labeled "colorful" characters who dominated the political landscape and wrangled backroom deals to get what they wanted. Moreover, he was keenly aware of the larger contemporary context for his political studies: the state's oil-based economy, which brought fabulous, untold riches for a few; and its cotton economy, which brought backbreaking, unremitting toil for the many, including almost all Mexican Americans and African Ameri- 
cans. Impoverished whites were little better off than their disenfranchised counterparts, but at least they were a valued constituency of the Democrats, and party regulars gave them their due, if only in a rhetorical way and only right before election day.

I arrived at UT in 2008, just a couple of years before Norman retired. With a shared love of southern history, we soon forged a connection that I valued. After he moved to an assisted living home here in Austin in 2013, we continued to keep in touch. Norman never used a computer, so he had no email address. But I would call him on the phone and make a lunch date, and we would enjoy hashing over the week's news headlines. His mind was as sharp as ever, and I considered it a rare privilege to listen to his entertaining stories about the historical roots of any number of current political scandals and debacles. Every morning he still read through a stack of newspapers and journals, and though lacking a copying machine, he still preserved items of interest by cutting them out and filing them away. He would invariably write a letter of thanks after we had met. In his last to me, in the spring of 2014, he offered to talk to one of my students who was writing a research paper on the Texas Klan in the 1920s. Norman Brown was a generous scholar, teacher, and friend to the very end.

Special thanks to those who provided their reminiscences and thoughts on Norman: David Brown, Josiah Daniel, Barbara White Stuart, Michael Stoff, Bill Brands, Neil Kamil, Clarence "Bud" Lasby, Howard Miller, Evan Ross, and George Forgie.

JACQUELINE JONES, Ellen C. Temple Chair in Women's History and Mastin Gentry White Professor of Southern History, University of Texas at Austin 